\title{
Arrowleaf clover: potential for dryland farming systems in New Zealand
}

\author{
P.M. EVANS ${ }^{1}$ and A. MILLS ${ }^{2}$ \\ ${ }^{I}$ DLF Seeds PO Box 16-826, Hornby, Christchurch 8441, Canterbury \\ ${ }^{2}$ Agriculture and Life Sciences Division, PO Box 84, Lincoln University, Canterbury \\ pe@dlfseeds.co.nz
}

\begin{abstract}
Arrowleaf clover (Trifolium vesiculosum L.) is a late maturing annual legume which has the potential to be used in a range of farming systems such as finishing lambs through to silage production and building soil fertility for future cropping. An experiment at Lincoln University, Canterbury, evaluated the performance of 'Arrotas' arrowleaf clover relative to white and subterranean clover from 23 May to 20 December 2007. By the 20/12/2007, 'Arrotas' produced $9800 \mathrm{~kg} \mathrm{DM} / \mathrm{ha}$ compared $(\mathrm{P}<0.001)$ with $3370 \mathrm{~kg} \mathrm{DM} / \mathrm{ha}$ from subterranean and $1790 \mathrm{~kg} \mathrm{DM} /$ ha from white clover. Metabolisable energy in late December was similar for all clovers. Results in Australia at similar latitudes and rainfall regimes to parts of the North and South Island of New Zealand suggest that 'Arrotas' could be successfully incorporated into local dryland systems.
\end{abstract}

Keywords: climate evaluation, $T$. repens, $T$. subterraneum, T. vesiculosum, dry matter yield

\section{Introduction}

In New Zealand dryland agricultural systems, arrowleaf clover (T. vesiculosum), a self regenerating annual clover native to the Mediterranean region, could play an important role. It has been cultivated in parts of the USA since the 1960s (Hoveland \& Evers 1995) and in Australia since the 1980s (Wiley 1994). In Brazil, it increased animal liveweight when used in mixtures with oats (Avena sativa) or annual ryegrass (Lolium multiflorum) (Lobato et al. 1993).

Arrowleaf clover is an aerial seeding species suited to well drained sandy or clay soils with pH 5-7 (Evans 2006). The species is hard seeded and, because of its late flowering, extends the growth season by around 6 weeks when compared with other annual legumes such as subterranean clover (T. subterraneum) (Riffkin et al. 2001; Zhang \& Evans 2004). In Australia, at latitudes similar to New Zealand, it persists in areas with 500-900 $\mathrm{mm} / \mathrm{yr}$ rainfall. This indicates it may be suited to dryland areas of the east coast of New Zealand.

In this paper we examine the hypothesis that in areas with similar climatic conditions to those in which it has previously been tested (such as Launceston in Tasmania and Hamilton in Victoria, Australia) 'Arrotas' arrowleaf clover may contribute to local agricultural dryland systems.

\section{Materials and Methods}

An experiment comparing three legume species was established at Lincoln University, Canterbury on a Templeton silt loam soil of variable depth. In spring 2005, the site was used to grow lettuce (Lactuca sativa). On 27/12/2005, following soil tests, $400 \mathrm{~kg} / \mathrm{ha}$ Nitrophoska $(12,10,10,1)$ was applied to the experimental area. No fertilisers have been applied since this time. A high Olsen $\mathrm{P}(70)$ reflected the previous site use as the piggery and poultry unit for $\sim 50$ years up to the mid 1950 s. In autumn 2006, 'Moata' short rotation ryegrass was sown. This was sprayed out with glyphosate $(540 \mathrm{~g} / \mathrm{L}$ ai) at $5 \mathrm{~L} / \mathrm{ha}$ with Pulse as a surfactant on $2 / 5 / 2007$. The site was ploughed, dutch harrowed and rolled on 10/5/2007 and 22/5/2007.

\section{Experimental design}

A randomised complete block (RCB) experiment, with four replicates, was drilled with an Øyjoord cone seeder on 23/5/2007. Treatments were monocultures of 'Nomad' white clover (T. repens) as a control, 'Leura', the latest maturing commercially available subterranean clover ( $T$. subterraneum) and 'Arrotas' arrowleaf clover ( $T$. vesiculosum) monocultures sown into $2.1 \times 9.0 \mathrm{~m}$ plots at rates to achieve a target population of 333 viable plants/ $\mathrm{m}^{2}$ based on germination tests. The annual clovers were freshly inoculated with appropriate commercially available rhizobial strains prior to sowing. For white clover Group B inoculant (Rhizobium leguminosarum bv. trifolii TA1) was applied while subterranean and arrowleaf clovers were inoculated with Group C $(R$. leguminosarum bv. trifolii WSM1325).

\section{Environmental conditions}

Monthly rainfall during 2007 (Fig. 1a) was less than the 1975-2002 mean (LTM), in May, August, September and November but was $30 \mathrm{~mm}$ above average in October. Mean monthly air temperature (Fig. 1b) followed the long-term seasonal pattern except it was $2.7^{\circ} \mathrm{C}$ warmer in May 2007 and $0.8^{\circ} \mathrm{C}$ cooler in June.

\section{Measurements}

Seedling emergence was measured from $2 \times 1.0 \mathrm{~m}$ drill rows per plot on 26/6/2007. Dry matter (DM) production $(\mathrm{kg} / \mathrm{ha})$ was measured three times between sowing and the final harvest on 20/12/2007. On 12/9/2007, 30/10/ 
Figure 1 Monthly (a) rainfall $(\mathrm{mm})$ and $(\mathrm{b})$ mean monthly air temperature $\left({ }^{\circ} \mathrm{C}\right)$ at Lincoln, Canterbury in 2007. Solid lines are long-term (1975-2002) monthly means. Data were recorded at the Broadfields Meteorological station located $2 \mathrm{~km}$ north of the experimental area.
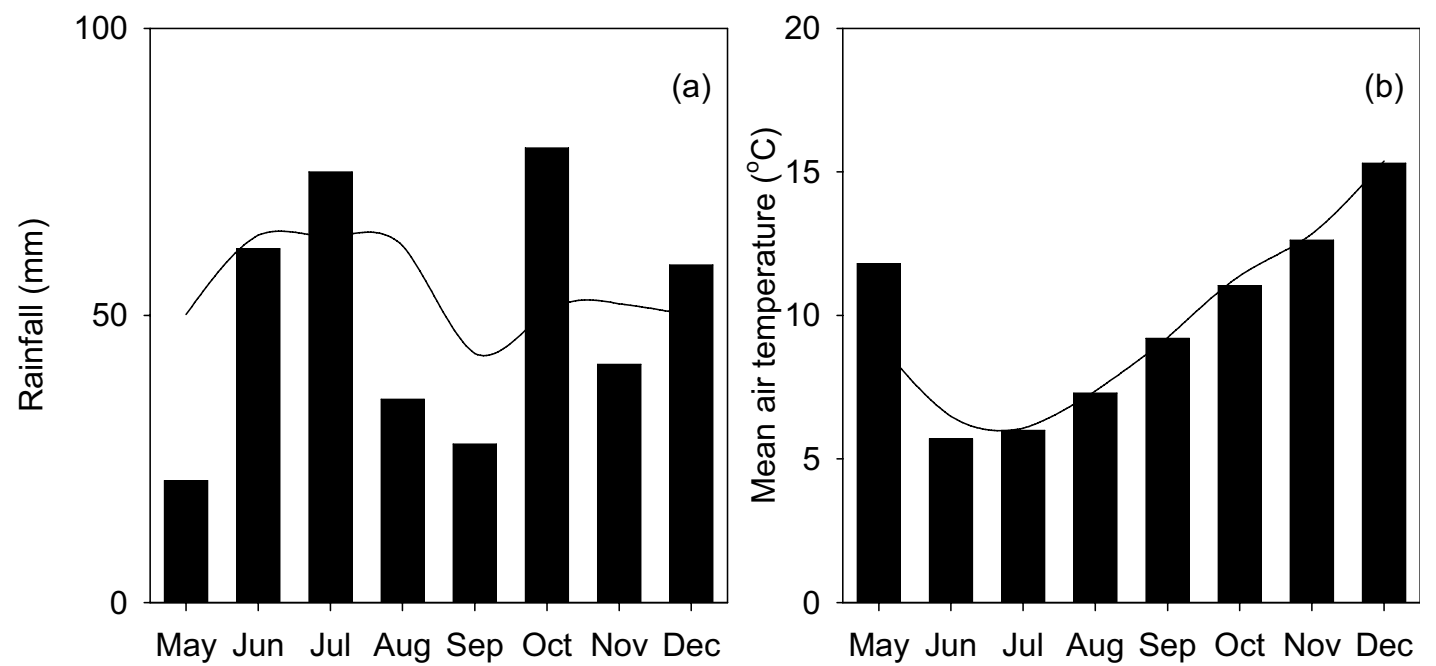

Month

2007 and 20/12/2007, yield was determined in each plot by cutting a $0.2 \mathrm{~m}^{2}$ quadrat to ground level with a set of electric clippers. Subsamples were taken to determine yield of the sown clovers and samples were then dried to a constant weight. Sown clover samples, which included leaf, stem, petiole, flowers/buds, and dead material were then ground in a Cylotec mill and nutritional analysis of the bulk clover samples was conducted by near infra-red spectroscopy (NIRS). Plots were then grazed in common by ewes and the experiment was terminated before arrowleaf clover had fully matured and set seed.

On 3/12/2007, random samples were taken to ground level from one replicate to quantify the contribution of leaf, petiole, stem, flowers/buds and dead material to standing DM, but yield was not measured. Leaf, stem and petiole samples were ground and sent for nutritional analysis by (NIRS).

\section{Climate comparisons}

CLIMEX is a dynamic simulation model which enables the estimation of an animal or plant's geographic distribution and relative abundance as determined by climate variables (Sutherst et al. 2007). The model was first described by Sutherst \& Maywald (1985), and the approach was used in plant breeding by Bennett et al. (1998) to match climatic similarities between areas in the Mediterranean basin and southern Australia.

This software was used to search the meteorological database contained within CLIMEX version 3 for locations with climates similar to that of a nominated location. The match index is the product of five parameters, which individually indicate the level of similarity for average monthly maximum daily temperature, average monthly minimum daily temperature, average monthly rainfall, rainfall pattern and the relative humidity at 9 am and $3 \mathrm{pm}$. The total similarity between the specified location and any other location is calculated by averaging the similarity values of the five parameters. In this study we selected locations in New Zealand receiving less than $1000 \mathrm{~mm}$ of annual rainfall and compared them with locations in SE Australia where 'Arrotas' arrowleaf clover is well adapted.

\section{Results \\ DM production}

On 27/6/2007 (34 DAS) the plant populations were lowest $(\mathrm{P}<0.001)$ for white clover $\left(119\right.$ plants $\left./ \mathrm{m}^{2}\right)$ and highest (333 plants/ $\mathrm{m}^{2}$ ) in the subterranean clover treatment. There were $228 \mathrm{plants} / \mathrm{m}^{2}$ in arrowleaf clover plots. This indicated field emergence of $36 \%$ for white clover, $68 \%$ for arrowleaf and $100 \%$ for subterranean clover.

At the first harvest on 12/9/2007 (112 DAS), subterranean clover had produced $220 \mathrm{~kg} \mathrm{DM} / \mathrm{ha}$ which was $5-8$ times greater $(\mathrm{P}<0.01)$ than the $36 \pm 23.5 \mathrm{~kg}$ $\mathrm{DM} /$ ha produced by 'Arrotas' or white clover monocultures (Fig. 2). At 161 DAS (31/10/2007) both subterranean $(3220 \mathrm{~kg} \mathrm{DM} / \mathrm{ha})$ and arrowleaf $(2120 \mathrm{~kg}$ $\mathrm{DM} / \mathrm{ha}$ ) clovers had higher yields $(\mathrm{P}<0.01)$ than white clover (495 kg DM/ha). Between the first and second harvests mean daily growth rates were $62 \mathrm{~kg} \mathrm{DM} / \mathrm{ha} / \mathrm{d}$ for subterranean and $42 \mathrm{~kg} \mathrm{DM} / \mathrm{ha} / \mathrm{d}$ for arrowleaf clover and both were faster $(\mathrm{P}<0.01)$ than the $10 \mathrm{~kg} \mathrm{DM} / \mathrm{ha} / \mathrm{d}$ from white clover. At this time, 'Leura' had extensive 
Figure 2 Dry matter production (kg DM/ha) between sowing (23/5/2007) and end of regrowth (20/12/2007) for 'Nomad' white clover, 'Leura' subterranean clover and 'Arrotas' arrowleaf clover at Lincoln University, Canterbury. Error bars are LSD $(P<0.05)$.

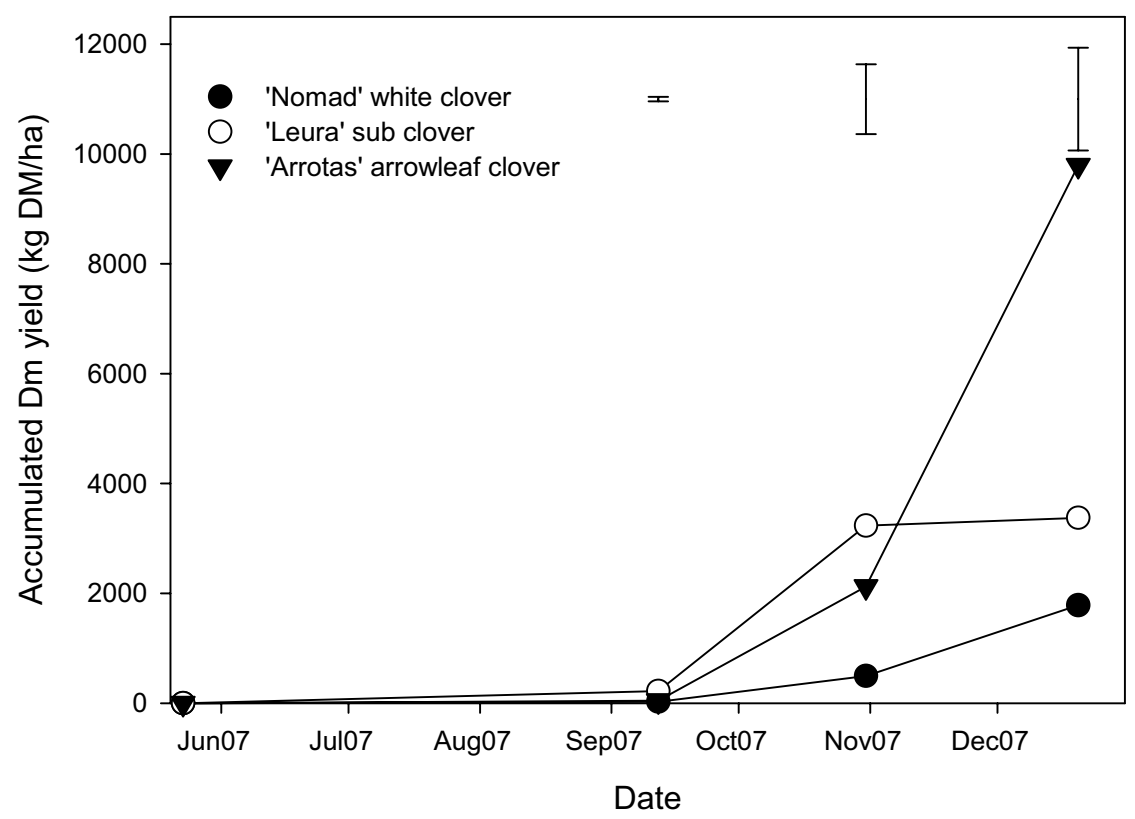

Table 1 Percentage (\%) contribution to standing DM of leaf, petiole and stem material, neutral detergent fibre (NDF, g/kg DM), acid detergent fibre (ADF, g/kg DM), water soluble carbohydrate (CHO, g/kg DM), metabolisable energy (ME, MJ ME/kg DM) and nitrogen concentration (N\%) from grab samples taken in Replicate 1 on 3/12/2007. Nutritive analysis was not conducted on flowers/buds or dead components.

\begin{tabular}{|c|c|c|c|c|c|c|c|}
\hline Species & Component & $\%$ & NDF & ADF & WSC & ME & $\mathrm{N} \%$ \\
\hline Arrowleaf & $\begin{array}{l}\text { Leaf } \\
\text { Petiole } \\
\text { Stem } \\
\text { Flowers/buds } \\
\text { Dead }\end{array}$ & $\begin{array}{c}23 \\
9 \\
64 \\
<1 \\
3\end{array}$ & $\begin{array}{l}223 \\
351 \\
449\end{array}$ & $\begin{array}{l}179 \\
286 \\
326\end{array}$ & $\begin{array}{c}64 \\
219 \\
381\end{array}$ & $\begin{array}{l}10.6 \\
10.9 \\
10.6\end{array}$ & $\begin{array}{l}4.9 \\
1.4 \\
1.2\end{array}$ \\
\hline Subterranean & $\begin{array}{l}\text { Leaf } \\
\text { Petiole } \\
\text { Stem } \\
\text { Flowers/buds } \\
\text { Dead }\end{array}$ & $\begin{array}{c}21 \\
27 \\
39 \\
6 \\
7\end{array}$ & $\begin{array}{l}198 \\
309 \\
282\end{array}$ & $\begin{array}{l}178 \\
275 \\
243\end{array}$ & $\begin{array}{l}139 \\
277 \\
303\end{array}$ & $\begin{array}{l}11.1 \\
11.5 \\
11.5\end{array}$ & $\begin{array}{l}3.8 \\
1.4 \\
1.3\end{array}$ \\
\hline White & $\begin{array}{l}\text { Leaf } \\
\text { Petiole } \\
\text { Stem } \\
\text { Flowers/buds } \\
\text { Dead }\end{array}$ & $\begin{array}{c}31 \\
31 \\
32 \\
6 \\
0\end{array}$ & $\begin{array}{l}192 \\
300 \\
331\end{array}$ & $\begin{array}{l}164 \\
279 \\
263\end{array}$ & $\begin{array}{l}114 \\
256 \\
176\end{array}$ & $\begin{array}{l}12.1 \\
11.8 \\
11.3\end{array}$ & $\begin{array}{l}5.1 \\
2.0 \\
2.7\end{array}$ \\
\hline
\end{tabular}

flower and burr formation whereas 'Arrotas' and 'Nomad' remained vegetative.

At the final harvest (20/12/2007,211 DAS), arrowleaf clover yield of $9800 \mathrm{~kg} \mathrm{DM} /$ ha was greater $(\mathrm{P}<0.001)$ than the $3370 \mathrm{~kg} \mathrm{DM} /$ ha produced by subterranean and the $1790 \mathrm{~kg} \mathrm{DM} /$ ha from white clover. Figure 2 shows that DM production by subterranean clover reached a plateau between the second and third harvests as its life cycle ended and material began to senesce resulting in a net DM gain over a $50 \mathrm{~d}$ period of $140 \mathrm{~kg} \mathrm{DM} / \mathrm{ha}$.
Between the second and third harvests, mean daily growth rate of arrowleaf was $153 \mathrm{~kg} \mathrm{DM} / \mathrm{ha} / \mathrm{d}$ and higher $(\mathrm{P}<0.001)$ than the 3 and $26 \mathrm{~kg} \mathrm{DM} / \mathrm{ha} / \mathrm{d}$ from subterranean and white clover, respectively. 'Arrotas' had entered the reproductive phase and flowers were beginning to senesce by late December.

Random samples from the 3/12/2007 showed stem material represented $64 \%$ of arrowleaf, $39 \%$ of subterranean and $32 \%$ of white clover standing DM (Table 1). As expected, N\% was highest (3.8-5.1\%) in 
Table 2 Neutral detergent fibre (NDF, g/kg DM), acid detergent fibre (ADF, g/kg DM), water soluble carbohydrate ( $\mathrm{CHO}, \mathrm{g} / \mathrm{kg} \mathrm{DM})$, metabolisable energy (ME, MJ ME/kg DM) and nitrogen concentration (N\%) from replicated bulk clover samples taken on 20/12/2007. Bulk clover samples contained leaf, stem, petiole, flowers/buds, and senesced leaves.

\begin{tabular}{|c|c|c|c|c|c|}
\hline Species & NDF & ADF & WSC & $\mathrm{ME}$ & $\mathrm{N} \%$ \\
\hline Arrowleaf & 386 & 295 & 231 & 10.4 & 1.6 \\
\hline Subterranean & 346 & 280 & $126^{a}$ & 10.4 & $2.1_{\mathrm{b}}^{\mathrm{c}}$ \\
\hline White & 317 & 229 & 94 & 11.1 & 3.6 \\
\hline Mean & 349 & 268 & $150^{b}$ & 10.6 & $2.5^{\mathrm{a}}$ \\
\hline SEM & 17.7 & 16.6 & 17.1 & 0.9 & 0.1 \\
\hline Signif. ${ }^{1}$ & NS & NS & $\star *$ & NS & $* * *$ \\
\hline
\end{tabular}

${ }^{1} \mathrm{NS}-$ not significant; ${ }^{* *} \mathrm{P}<0.01 ;{ }^{* * *} \mathrm{P}<0.001$

green leaf material compared with petiole and stems. The NDF of stem material of arrowleaf clover was $449 \mathrm{~g} / \mathrm{kg}$ DM which was consistent with a highly lignified stem. Water soluble carbohydrate levels in the 'Arrotas' stem were $26 \%$ and $116 \%$ greater than those of stem material from subterranean or white clover, respectively. Metabolisable energy was reasonably consistent across species and components although leaf material of arrowleaf clover had a lower ME than that of white clover.

At the final harvest on 20/12/2007, ME of samples containing leaf, stem and reproductive material was 10.7 $\pm 0.25 \mathrm{MJ} \mathrm{ME} / \mathrm{kg} \mathrm{DM}$ and similar for all clovers (Table 2). Water soluble carbohydrate levels in arrowleaf clover $(231 \mathrm{~g} / \mathrm{kg} \mathrm{DM})$ were greater $(\mathrm{P}<0.01)$ than those from subterranean $(126 \mathrm{~g} / \mathrm{kg} \mathrm{DM})$ and white clover $(94$ $\mathrm{g} / \mathrm{kg} \mathrm{DM})$ and white clover had the highest $(\mathrm{P}<0.001)$ nitrogen content $(3.6 \%)$ of the three species.

\section{Climate evaluation}

Two areas in Australia where 'Arrotas' showed excellent adaptation in a variety of different agricultural systems were Launceston, Tasmania, and Hamilton in SW Victoria. The best match to Launceston in New Zealand was Waipukurau (93\%) and the closest location to Hamilton, Victoria was Blenheim with $91 \%$ fit. St Helens and Orford in Tasmania matched Blenheim well with fits of 91 and $92 \%$ respectively. Napier in New Zealand matched St Helens (Tas), Lakes Entrance (Vic) and Warrnambool (Vic) well with a fit of $92 \%$ for all three sites. Christchurch, close to the experiment reported here matched Launceston and Hamilton at 87 and $84 \%$ respectively.

\section{Discussion}

The results show 'Arrotas' has the ability to extend the growing season compared with the late flowering 'Leura' subterranean clover (Fig. 2). Mean daily growth rate of 'Leura' was $140 \mathrm{~kg} \mathrm{DM} / \mathrm{ha} / \mathrm{d}$ between 12/9/2007 and 30/ $10 / 2007$, when mean air temperature was $10.6^{\circ} \mathrm{C}$. However, between $31 / 10 / 2007$ and 20/12/2007, when mean air temperature was $13.8^{\circ} \mathrm{C}$, arrowleaf had a mean daily growth rate of $153 \mathrm{~kg} \mathrm{DM} / \mathrm{ha} / \mathrm{d}$ compared with 26 $\mathrm{kg} \mathrm{DM} / \mathrm{ha} / \mathrm{d}$ by white clover and $3 \mathrm{~kg} \mathrm{DM} / \mathrm{ha} / \mathrm{d}$ by subterranean clover. Specifically, arrowleaf clover had a longer lifecycle than subterranean clover and was able to utilise late spring/early summer rainfall which is variable and unpredictable (Fig. 1). This supports previous work that reported 'Arrotas' was late maturing and extended the growing season by several weeks compared with subterranean, balansa (T. michelianum) or Persian ( $T$. resupinatum) clovers (Zhang et al. 2004). In Victoria, 'Arrotas' produced as much, or more, DM than the other annual legumes and over $60 \%$ of total production occurred from November onwards compared with $30 \%$ for the other annual legumes (Zhang et al. 2004). The extension of the growing season should result in improved animal performance through increased carrying capacity compared with white and subterranean clovers in late spring. Fresh stems of 'Arrotas' were grazed well by stock after the final harvest (visual observation) and preliminary results have suggested high levels of water soluble carbohydrates in the stems (Table 1) may contribute to grazing of lignified stems. The high proportion of stem material ensured that WSC levels in bulk clover samples at the final harvest remained higher than those of subterranean or white clovers. As expected, the annual legumes, which had begun to flower and senesce, had lower $\mathrm{N}$ content than perennial white clover which was still vegetative.

Holmes et al. (2005) demonstrated that 'Arrotas' extended the growing season by $4-6$ weeks in Hamilton, Victoria, compared to 'Leura' subterranean clover and total lamb production from 'Arrotas' in late spring/early summer was $63 \%$ more than from 'Leura'. Inclusion of 'Arrotas' with perennial ryegrass, increased the utilisation of the low quality grass during early/mid summer by at least $1000 \mathrm{~kg} \mathrm{DM} / \mathrm{ha}$ (Thompson 2006) and lambs grew quicker on arrowleaf clover than expected from the quality of the feed on offer. It was hypothesised that tannin levels in the leaf between 2 and 5\% (Hoveland et al. 1972) may have been a contributing factor.

In Australia, 'Arrotas' is adapted to pasture:crop rotations and shows excellent self regeneration in the year following cropping. In the third year of the rotation, 'Arrotas' had a 
soil seed bank of $950 \mathrm{~kg} / \mathrm{ha}$, and in the fifth year it produced 12.8 t DM/ha (Evans et al. 2003; Zhang \& Evans 2004; Zhang et al. 2004). High levels of hard seed and late seed set in summer precludes it from regenerating in the second year. Therefore, in New Zealand it may be necessary to direct drill an annual or perennial ryegrass in the second year following a pure stand that has been allowed to set seed. Alternatively, arrowleaf clover has performed well when direct drilled into hard grazed perennial grass pastures (Thompson 2006). It is important to establish a crop or grass in the second year to exploit the fixed $\mathrm{N}$ as arrowleaf clover with yields in excess of $10 \mathrm{tDM} / \mathrm{ha}$ will input $250 \mathrm{~kg} \mathrm{~N} / \mathrm{ha}$ into the system $(25 \mathrm{~kg} \mathrm{~N} / \mathrm{t} \mathrm{DM})$ (Peoples et al. 1998). A third option is to leave the pasture ungrazed and, after seed set, use the crop as standing hay or cut for silage. Self regeneration will occur every year from its third season onwards (Zhang et al. 2004).

The close fit between a range of sites in Australia where the plant performs well and places in New Zealand where dryland agriculture is practised suggest that 'Arrotas' could be valuable in local pasture and pasture/crop rotation systems. Initial results are encouraging, and warrant further work to test this hypothesis.

\section{Conclusions}

- 'Arrotas' produced $9800 \mathrm{~kg} \mathrm{DM} / \mathrm{ha}$ between May and December and had a mean daily growth rate of $153 \mathrm{~kg}$ $\mathrm{DM} / \mathrm{ha} / \mathrm{d}$ between 31/10/2007 and 20/12/2007 when mean air temperature was $13.8^{\circ} \mathrm{C}$.

- The longer lifecycle, relative to the later maturing commercially available subterranean clover cultivar, meant 'Arrotas' could utilise rainfall in late spring/early summer typical of dryland systems on the east coast of New Zealand.

- Climate suitability was $>84 \%$ for a range of dryland east coast locations from Canterbury northwards.

\section{ACKNOWLEDGEMENTS}

The authors would like to thank Bob Reid for assistance in using the CLIMEX model. A. Mills acknowledges financial assistance from Meat \& Wool New Zealand through the FoRST Pastoral21 programme for supporting the field experiment.

\section{REFERENCES}

Bennett, S.J.; Saidi, N.; Enneking, D. 1998. Modelling climatic similarities in Mediterranean areas: a potential tool for plant genetic resources and breeding programmes. Agriculture, Ecosystems and Environment 70: 129-143.

Evans, P.M.; Zhang, X; Riffkin, P.A. 2003. Annual pasture legumes for farming systems in cool temperate areas with summer soil moisture deficits. Legumes for Dryland Pastures. Grassland Research and Practice Series 11: 149-154.
Evans, P.M. 2006. Agriculture Notes, Arrowleaf clover. AG0576 ISSN 1329-8062. State of Victoria, Department of Primary Industries, Australia.

Holmes, J.; Kennedy, A.J.; Thompson, A.N. 2005. Arrowleaf clover for growing lambs in late spring/early summer in southwest Victoria. p. 120. In: Proceedings of the 46th Annual Conference of the Grassland Society of Southern Australia, July 15-17, Ballarat, Victoria, Australia.

Hoveland C.S.; McCormick, R.F.; Anthony W.B. 1972. Productivity and forage quality of Yuchi arrowleaf clover. Agronomy Journal 64: 552-555.

Hoveland C.S.; Evers G.W. 1995. Arrowleaf, crimson and other annual clovers. pp 249-260. In: Forages 5th Edition Vol. 1. An Introduction to Grasslands Agriculture. Eds. Barnes, R.F.; Miller, D.A.; Nelson, C.J. IOWA State University Press, AMES, Iowa.

Lobato, J.F.P.; Albospino, B.H.J.; Magalhaes, F.R.; Taher, A.A. 1993. Effect of grazing order on live-weight gain of young female beef cattle.pp. 1525-1526. In: Proceedings of the XVII International Grasslands Congress, Palmerston North, New Zealand and Rockhampton, Australia, 13-16 February 1993.

Peoples, M.B.; Gault, R.R.; Angus, J.F.; Bowman, A.M.; McCallum, M. 1998. Comparisons of the efficiency of nitrogen fixation in pastures. pp. 807-810. In: Proceedings of the 9th Australian Agronomy Conference, WaggaWagga, Australia.

Riffkin P.A.; Evans, P.M.; Wright, A.J. 2001. Extending pasture quality later into the season. Proceedings of the 10th Australian Agronomy Conference, Hobart. www.regional.org.au/au/asa/2001/

Sutherst, R.W.; Maywald, G.F.; Kriticos D. 2007. CLIMEX for windows version 3.0 User's guide. CSIRO and CRC for Tropical Pest Management, Brisbane.

Sutherst, R.W.; Maywald G.F. 1985. A computerised system for matching climates in ecology. Agriculture, Ecosystems and Environment 13: 281-299.

Thompson, A. 2006. Morelamb quality pastures. Final Report to Meat \& Livestock Australia. Published by Meat \& Livestock Australia Ltd, Project code MS.004

Wiley, T. 1994. Alternative legumes and salinity in Southern Australia: present situation and future research requirements. pp. 139-142. In: Proceedings of the 2nd National Alternative Pasture Legumes Workshop 1993. Primary Industries South Australia, Technical Report 219.

Zhang, X.; Evans, P.M.; Riffkin, P.A. 2004. Performance of annual pasture legumes in cropping rotations in the cool temperate zone of south eastern Australia. Australian Journal of Experimental Agriculture, 44: 863-871.

Zhang, X.; Evans, P.M. 2004. Grain yield production in relation to plant growth of wheat and canola following clover pastures in southwest Victoria. Australian Journal of Experimental Agriculture 44: 1003-1012. 